\title{
Biomarkers in Sepsis: Value of Procalcitonin in Diagnosis and Prognostication
}

\section{Ozgur Karcioglu*}

Department of Emergency Medicine, Istanbul Research and Training Hospital, Turkey

*Corresponding author: Ozgur Karcioglu, Department of Emergency Medicine, Istanbul Research and Training Hospital, Turkey, Tel: 0.505.5252399; E-mail: okarcioglu@gmail.com

Received date: July 23, 2018 Accepted date: July 25, 2018 Published date: July 27, 2018

Copyright: @2018 Karcioglu O. This is an open-access article distributed under the terms of the Creative Commons Attribution License, which permits unrestricted use, distribution, and reproduction in any medium, provided the original author and source are credited.

\begin{abstract}
Sepsis is the most common way of death in critical patients. The mortality rate of septic shock (SS) lies between $20 \%$ and $40 \%$ in developed countries, although varies substantially from center to center. The definitions of Sepsis were revised in the conference held by The European Society of Intensive Care Medicine (ESICM) and Society of Critical Care Medicine (SCCM) in 2016 Sepsis-3 as "life-threatening organ dysfunction caused by a deregulated host response to infection".
\end{abstract}

Keywords: Biomarker; Sepsis; Procalcitonin; Diagnosis; Diagnostic value; Outcome

\section{Introduction}

The most important predictors of mortality in septic patients are early recognition of deterioration to SS and expedient treatment with antibiotics. The diagnosis can be overlooked in the early phases of sepsis much more commonly than most other diseases. New proposals point out new criteria for the diagnosis of sepsis cases "life-threatening organ dysfunction associated with proven infectious process". In the new proposals, health community disregarded definitions such as "severe sepsis" and "Systemic Inflammatory Response Syndrome" (SIRS) criteria in the diagnosis and management of the entity [1-4].

\section{Biomarkers in Sepsis: When and How to use Procalcitonin in Sepsis and Septic Shock?}

Lactate and procalcitonin (PCT) are among the most commonly cited biomarkers in the septic process. A recent Australian study disclosed that hyperlactatemia was proven to be more accurate in predicting mortality when compared to hypotension unresponsive to fluid replacement [5]. Shetty et al. indicated that lactate levels $>2$ $\mathrm{mmol} / \mathrm{L}$ in ED patients who were suspected to have sepsis are to be viewed as a risk predictor [6]. Also, these high levels of lactate was associated with in-hospital mortality rates greater than 10 percent and stay times in ICU longer than 72 hours in patients with respiratory and abdominal infectious foci in this study.

\section{PCT}

Meta-analytic data involving 16514 patients demonstrated that PCT levels with a cut-off of $0.5 \mathrm{mmol} / \mathrm{L}$ had a sensitivity of $76 \%$ and a specificity of $69 \%$ to rule out bacteremia in those with bloodstream infections [7]. Nishikawa et al. used the same cut-off level and found that the area under curve of PCT in diagnosing bacteremia was larger than that of CRP (0.79 vs 0.66, respectively) [8]. Cha et al. indicated that PCT levels should not be used as a sole diagnostic for sepsis without blood cultures, evidenced by inability to rule out one-fourth of those with nosocomial sepsis when a PCT cut-off level of $0.27 \mathrm{ng} / \mathrm{mL}$ was used [9].

On the other hand, researchers cited that PCT and neutrophil/ lymphocyte count ratio could be used in the diagnosis of SS and AUC was found to be higher when these two markers are used together [10].

Six studies' meta-analysis disclosed that PCT had a high sensitivity for ICU patients $(0.84)$, but a low specificity (0.64) for identifying secondary bacterial infections among patients with influenza [11]. It can be used to rule-out influenza pneumonia for its negative likelihood ratio was reasonably low ( $\mathrm{LR}=0.26$; $95 \% \mathrm{CI}: 0.17-0.40$ ).

There is data claiming that the level of PCT over the first 24 hours regardless of the initial severity classification accurately predicts mortality in sepsis patients in the critical care unit [12]. More interestingly, an $80 \%$ decrease in PCT level over $72 \mathrm{~h}$ carried a $90 \%$ NPV for mortality.

Porfyridis et al. evaluated the diagnostic value of clinical pulmonary infection score (CPIS), CRP, and PCT and to compare the accuracy of pneumonia severity scores (confusion, urea nitrogen, breathing frequency, blood pressure, $>65 \mathrm{y}$ of age [CURB-65]; pneumonia severity index; nursing home acquired pneumonia (NHAP) index; systolic blood pressure, multilobar involvement, albumin, breathing frequency, tachycardia, confusion, oxygen, arterial pH [SMART-COP]; and systolic blood pressure, oxygen, age $>65 \mathrm{y}$, breathing frequency [SOAR]) in predicting inpatient mortality from NHAP [13]. Patients with Gram (+) pneumonia had significantly higher CRP and PCT levels. PCT levels averaged $4.6+-5.4 \mathrm{ng} / \mathrm{mL}$ in mortal patients, while survivors had an average of $0.8+-0.9 \mathrm{ng} / \mathrm{mL}(\mathrm{p}<0.001)$. CPIS, PCT and CRP proved to have high accuracy in diagnosis of pneumonia, while PCT and CURB-65 was stronger in predicting in-hospital mortality when compared to other tools. Nosocomial bloodstream infections increased in accord with renal failure $(0.12 \mathrm{ng} / \mathrm{mL}$ with estimated glomerular filtration rate $[\mathrm{eGFR}] \geq 60 \mathrm{~mL} / \mathrm{min} / 1.73 \mathrm{~m}^{2} ; 0.84 \mathrm{ng} / \mathrm{mL}$ with $30 \leq \mathrm{eGFR}<60 \mathrm{~mL} / \mathrm{min} / 1.73 \mathrm{~m}^{2} ; 1.71 \mathrm{ng} / \mathrm{mL}$ with $\mathrm{eGFR}<30$ $\mathrm{mL} / \mathrm{min} / 1.73 \mathrm{~m}^{2}$ ). The evidence that the cutoff value of PCT for identifying sepsis was higher in patients with impaired renal function, are consistent with some other studies [14]. PCT cut-off levels in 
patients with kidney failure should be higher than healthy controls [15].

\section{Use in Elderly Patients}

PCT was also proven useful in elderly patients suspected for having bacteremia. Lee et al. reported that PCT was not inferior to other adults in diagnosing bacterial infection [16]. However, the imperfect accuracy of the test withheld recommendations on the use of the test in isolation. In a more recent study on elderly sepsis patients, PCT, IL-10, IL-6, and IL-5 were found useful in predicting ICU admission, but were not effective in predicting the death [17].

\section{H1N1 and PCT}

In the era of H1N1 pandemic of 2009, ICU patients with bacterial pneumonia had higher PCT levels than those having only H1N1 infection (average $6.2 \mathrm{mcg} / \mathrm{L}$ and $0.56 \mathrm{mcg} / \mathrm{L}$ ) [18]. The test had $80 \%$ sensitivity and $73.2 \% \mathrm{NPV}$ in predicting bacterial pneumonia with the cut-off level taken as $0.5 \mathrm{mcg} / \mathrm{L}$.

\section{Conclusion}

PCT is the most commonly investigated sepsis-specific biomarker via well-designed, prospective, randomized trials in different samples to establish an easy-to-use diagnostic tool which can help expedient patient care in the acute setting. Specifically, PCT was found superior to most other acute phase reactants and indicators, including CRP as a predictor of bacteremia and sepsis.

\section{References}

1. Liu V, Escobar GJ, Greene JD, Soule J, Whippy A, et al. (2014) Hospital deaths in patients with sepsis from 2 independent cohorts. JAMA 312: 90-92.

2. Singer M, Deutschman CS, Seymour CW, Shankar-Hari M, Annane D, et al. (2016) The third international consensus definitions for sepsis and septic shock (Sepsis-3). JAMA 315: 801-810.

3. Kumar A, Roberts D, Wood KE, Light B, Parrillo JE, et al. (2006) Duration of hypotension before initiation of effective antimicrobial therapy is the critical determinant of survival in human septic shock. Crit Care Med 34: 1589-1596.

4. Ju T, Al-Mashat M, Rivas L, Sarani B (2018) Sepsis rapid response teams. Crit Care Clin 34: 253-258.

5. Gotmaker R, Peake SL, Forbes A, Bellomo R (2017) Mortality is greater in septic patients with hyperlactatemia than with refractory hypotension. Shock 48: 294-300
6. Shetty AL, Thompson K, Byth K, Macaskill P, Green M, et al. (2018) Serum lactate cut-offs as a risk stratification tool for in-hospital adverse outcomes in emergency department patients screened for suspected sepsis. BMJ Open 8: e015492

7. Hoeboer SH, van der Geest PJ, Nieboer D, Groeneveld AB (2015) The diagnostic accuracy of procalcitonin for bacteraemia: A systematic review and meta-analysis. Clin Microbiol Infect 21: 474-481.

8. Nishikawa H, Shirano M, Kasamatsu Y, Morimura A, Kishi T, et al. (2017) Comparison between procalcitonin and $\mathrm{C}$-reactive protein in predicting bacteremias and confounding factors: A case-control study. Clin Chem Lab Med 55: 1043-1052.

9. Cha JK, Kwon KH, Byun SJ, Ryoo SR, Lee JH, et al. (2018). Clinical value of procalcitonin for suspected nosocomial bloodstream infection. Korean J Intern Med 33: 176-184

10. Ljungström L, Pernestig AK, Jacobsson G, Andersson R, Usener B, et al. (2017) Diagnostic accuracy of procalcitonin, neutrophil-lymphocyte count ratio, C-reactive protein, and lactate in patients with suspected bacterial sepsis. PLoS One 12: e0181704.

11. Wu MH, Lin CC, Huang SL, Shih HM, Wang CC, et al. (2013) Can procalcitonin tests aid in identifying bacterial infections associated with influenza pneumonia? A systematic review and meta-analysis. Influenza other respir viruses 7: 349-355.

12. Schuetz P, Maurer P, Punjabi V, Desai A, Amin DN, et al. (2013) Procalcitonin decrease over 72 hours in US critical care units predicts fatal outcome in sepsis patients. Crit Care 17: R115

13. Porfyridis I, Georgiadis G, Vogazianos P, Mitis G, Georgiou A. (2014). CReactive Protein, Procalcitonin, Clinical Pulmonary Infection Score, and Pneumonia Severity Scores in Nursing Home Acquired Pneumonia. Resp Care 59: 574-581

14. Contou D, d'Ythurbide G, Messika J, Christophe R, Antoine P et al. (2014). Description and predictive factors of infection in patients with chronic kidney disease admitted to the critical care unit. J In-fect 68: $105-115$

15. Lee WS, Kang DW, Back JH, Kim HL, Chung JH, et al. (2015) Cutoff value of serum procalcitonin as a diagnostic bio-marker of infection in end-stage renal disease patients. Korean J Intern 30: 198-204.

16. Lee SH, Chan RC, Wu JY, Chen HW, Chang SS, et al. (2013) Diagnostic value of procalcitonin for bacterial infection in elderly patients - a systemic review and meta-analysis. Int J Clin Pract 67: 1350-1357.

17. Lee WJ, Woo SH, Kim DH, Seol SH, Park SK, et al. (2016). Are prognostic scores and biomarkers such as procalcitonin the appropriate prognostic precursors for elderly patients with sepsis in the emergency department? Aging Clin Exp Res 28: 917-924

18. Pfister R, Kochanek M, Leygeber T, Brun-Buisson C, Cuquemelle E, et al. (2014) Procalcitonin for diagnosis of bacterial pneumonia in critically ill patients during $2009 \mathrm{H} 1 \mathrm{~N} 1$ influenza pandemic: A prospective cohort study, systematic review and individual patient data meta-analysis. Crit Care 18: R44. 